\title{
UPAYA PENCEGAHAN TERORISME DI PROVINSI RIAU (STUDI KASUS DITRESKRIMUM POLDA RIAU)
}

\author{
Silvi Dwi Rama, S.Sos
}

\begin{abstract}
Terrorism is a transnational crime most feared by the world, not to mention Indonesia. Already many who became victims of terrorism crimes one of the tragedy is the bom Bali that link hundreds of souls. In Indonesia, especially in Riau continue to spread terrorism prevention efforts so terrorism crime does not occur in Riau Province. Prevention needs to be done considering the province of Riau began as a transit area of terrorism because it is a region. The purpose of this research is to know what is done by Ditrekrimum Polda Riau in doing prevention of terrorism.The research conducted on Polda Riau which is located at Jalan Jenderal Sudirman no. 215 Pekanbaru, with the subject of research is Ditreskrimum Polda Riau and the result of his research is the prevention of terrorism in Riau Province by Ditreskrimum Polda Riau. The method used is qualitative research method with data technique is interview, observation and documentation. Data analysis using qualitative descriptive method. In this research the informant is Kasubdit 1 State Security Ditreskrimum Polda Riau and Kanit III Subdit 1 Ditreskrimum Polda Riau, as well as one member subdit I Ditreskrimum Polda Riau, as a complementary informant to support the research information. From the results of the research can be concluded that the efforts of terrorism have fulfilled the concept of (Darmawan, 2013). Prevention, prevention, prevention, prevention, prevention, prevention, mitigation, and repressive or arrest measures. In doing the prevention of Polda Riau Ditreskrimum also have conformity with awareness to other society, less effective performance of RT / RW area in which become target of terrorist is difficult to access area.
\end{abstract}

Keywords : Prevention, Terrorism

\section{Pendahuluan}

Negara Republik Indonesia adalah sebuah negara yang berlandaskan hukum, bahwa hukum di Indonesia dijunjung tinggi, sesuai dengan pasal 27 UUD 1945 "bahwa segala warga Negara bersamaan kedudukannya dalam hukum dan pemerintahan, dan wajib menjujung hukum dan pemerintahan itu dengan tidak ada kecualinya”. Sebagai basic Law (hukum dasar) UUD 1945 telah mengatur kedudukan warga Negara dan pemerintahan itu sendiri (Santoso; 1998: 64).

Sesuai dengan amanat undangundang Dasar 1945 maka dibentuklah aparat Negara penegak hukum yaitu Polri yang didasarkan UU no 2 tahun 
2002 tentang Kepolisian Negara

Republik Indonesia diatur dalam pasal 13 berbunyi “dalam mengemban tugas kepolisian mempunyai tugas pokok : memelihara keamanan dan ketertiban masyarakat,, menegakan hukum, melindungi, mengayomi dan melayani masyarakat.

Sebagai aparat penegak hukum Polri mengemban tanggung jawab yang sangat besar, mengingat tantangan perkembangan zaman maupun pengaruh globalisasi saat ini, setidaknya secara garis besar Polri dihadapkan pada 3 jenis dimensi kejahatan ; yaitu kejahatan transnasional, kejahatan konvensional, dan kejahatan kerah putih atau white collar crime. Kejahatan transnasional atau lintas batas meliputi ; Cyber crime, Terorisme, Human Trafficking, illegal maining, illegal fishing, Narkoba, dan lain-lain. Kejahatan konvensional seperti premanisme, pembunuhan, perampokan, penipuan dan sebagainya. Sedangan White Collar Crime terdapat modusmodus kejahatan , seperti korupsi, money loundering, kejahatan perbankan, kejahatan ekonomi dan fiscal, hingga kejahatan pasar modal. Dari berbagai macam kejahatan tersebut teroris adalah salah satu kejahatan yang paling ditakutkan oleh masyarakat Indonesia tak terkecuali di Provinsi Riau.

Defenisi terorisme itu sendiri tidak dapat ditemukan secara baku pada perundang-undangan yang ada, sering dianalogikan sebagai serangan-serangan terkoordinasi yang bertujuan membangkitkan perasaan teror terhadap sekelompok masyarakat dan umumnya memiliki tujuan politis. Berbeda dengan perang, aksi terorisme tidak tunduk pada tata cara peperangan seperti waktu pelaksanaan yang selalu tiba-tiba dan target korban jiwa yang acak serta sering kali merupakan warga sipil.

Gambaran umum tentang perkembangan organisasi terorisme di dunia (Arsip Polda Riau, 2017) :

a. Basque Fatherland \& Liberty (ETA)

b. Comunist Party of India (CPI) Maoist

c. Revolutionnary Armed Forces of Columbia (FARC)

d. Irish Republican Army (IRA)

e. Al Qaeda

Fenomena terorisme di Indonesia mulai berkembang pasca runtuhnya Orde baru 1998. Sejak tahun 2000, sejumlah pemboman telah terjadi di Indonesia, seperti bom dibeberapa gereja pada 
malam Natal 2000, bom Sari Club dan Paddy’s Café pada Oktober 2002. Hotel J.W Marriot meledak dua kali, yakni pada Agustus 2003 dan Juli 2009. Belakangan , aksi-aksi terror sering dilakukan secara terang-terangan kepada pihak yang dianggap berbeda pendapat atau keyakinan, misalnya dalam peristiwa pengeboman di Starbuck Sarinah Thamrin yang menewaskan dua orang yang merupakan anggota kepolisian yang sedang bertugas disana. Pengeboman tersebut jelas memperlihatkan bagaimana teroris mulai berani bermain terang-terangan didepan umum. Bom Bali satu dan bom Bali dua adalah peristiwa pengeboman terparah di Indonesia, Sekurang-kurangnya 22 orang tewas dan 102 lainnya luka-luka akibat ledakan yang terjadi di R.AJA's Bar dan Restaurant, Kuta Square, daerah Pantai Kuta dan di Nyoman Café Jimbaran.

$$
\text { Adapun salah satu tujuan }
$$
munculnya jaringan teroris di Indonesia ialah Ingin mendirikan negara Islam
Indonesia (NII), Daulah Islamiah (JI) dan membentuk Syariat Islam dengan menggantikan konstitusi \& 4 pilar berbangsa \& negara (Arsip Polda Riau).

Tidak bisa dipungkiri perkembangan jaringan teroris di Indonesia pada saat sekarang ini sudah mulai meluas ke pelosok - pelosok daerah yang tersebar di seluruh wilayah Indonesia.

Berdasarkan penjelasan di atas wilayah Riau juga termasuk menjadi salah satu sasaran dan tempat persembunyian para pelaku jaringan teroris Indonesia. Dimana wilayah Riau berbatasan langsung dengan dua negara sangat berpotensi sebagai wilayah yang menjadi target operasi teroris karena Riau merupakan daerah pintu masuk perdagangan dunia, meskipun kasus terorisme belum terlalu nampak di Provinsi Riau itu sendiri. Tabel dibawah menjelaskan beberapa kasus-kasus terorisme yang pernah terjadi di Provinsi Riau: 
Tabel 1.1 Kasus atau Perkara Yang Menyangkut Terorisme di Provinsi Riau

\begin{tabular}{|c|c|c|}
\hline No & Kasus & Sumber \\
\hline 1. & $\begin{array}{l}\text { Kasus Bom Malam Natal } 2000 \text { di Gereja Huria } \\
\text { Kristen Batak Protestan (HKBP) Pekanbaru, Riau, } \\
\text { yang menewaskan empat orang mulai } \\
\text { menunjukkan titik terang. }\end{array}$ & $\begin{array}{l}\frac{\text { http://webcache.googleuse }}{\text { rcontent.com/search?q=ca }} \\
\text { che:http://news.liputan6.co } \\
\text { m/read/26440/kasus-bom- } \\
\text { natal-di-pekanbaru-mulai- } \\
\text { terkuak } \\
\text { Di akses pada 20 } \\
\text { November 2016 }\end{array}$ \\
\hline 2. & $\begin{array}{l}\text { Detasemen khusus (Densus) } 88 \text { anti teror } \\
\text { mengamankan terduga teroris di Kabupaten Siak, } \\
\text { Riau Kamis, } 22 \text { Agustus 2013. Penangkapan ini } \\
\text { disebut melibatkan aparat kepolisian setempat. } \\
\text { Berdasarkan informasi yang berhasil dihimpun, } \\
\text { ada dua terduga teroris yang ditangkap di Pasar } \\
\text { Minggu, Kota Kandis. }\end{array}$ & $\begin{array}{l}\frac{\text { http://daerah.sindonews.co }}{\mathrm{m} / \text { read/774191/24/densus- }} \\
\frac{\text { 88-tangkap-dua-teroris-di- }}{\text { riau-1377157180 }} \\
\text { di akses pada } 20 \\
\text { November 2016. }\end{array}$ \\
\hline 3. & $\begin{array}{l}\text { Kamis, } 23 \text { Agustus } 2013 \text { Tim gabungan } \\
\text { Detasemen 88/Antiteror dan Polda Riau mampu } \\
\text { membekuk satu di antara empat orang napi kasus } \\
\text { teror yang melarikan diri dari Lapas Tanjung } \\
\text { Gusta, Medan, Sumatera Utara paska kerusuhan } \\
\text { yang pecah. }\end{array}$ & $\begin{array}{l}\text { http://www.beritasatu.com } \\
\text { /nasional/133418-agus- } \\
\text { sunyoto-napi-teroris- } \\
\text { tanjung-gusta-dibekuk-di- } \\
\text { riau.html } \\
\text { di akses pada } 20 \\
\text { November } 2016\end{array}$ \\
\hline 4. & $\begin{array}{l}\text { Polresta Pekanbaru melakukan penyelidikan dan } \\
\text { mengumpulkan semua informasi tentang Yud Sya } \\
\text { alias Kho (29) terduga pelaku terorisme yang } \\
\text { berhasil diamankan oleh tim Densus } 88 \text { Mabes } \\
\text { Polri, Jumaat (18/12/2015) lalu. Dengan identitas } \\
\text { sebagai warga Marpoyan Damai, Yud alias Kho } \\
\text { dibekuk saat berada di Majenang, Kabupaten } \\
\text { Cilacap, sekitar pukul 11.30 WIB. }\end{array}$ & $\begin{array}{l}\text { http://www.riaupos.co/960 } \\
\text { 23-berita-warga- } \\
\text { pekanbaru-terduga-teroris- } \\
\text { pernah-tersandung-kasus- } \\
\text { narkoba.html\#ixzz4NaEn } \\
\text { Qk77 di akses pada 20 } \\
\text { November } 2016\end{array}$ \\
\hline 5. & $\begin{array}{l}\text { Tim Gegana dari Satuan Brigade Mobil Polda } \\
\text { Riau, melumpuhkan dua orang terduga teroris, } \\
\text { Rabu (23/12/2015), yang disinyalir akan } \\
\text { meledakkan diri di salahsatu gereja di Provinsi } \\
\text { Riau. Aksi kelompok radikal itu terendus petugas, } \\
\text { yang curiga dengan gerak-gerik mereka. }\end{array}$ & $\begin{array}{l}\text { https://www.goriau.com/b } \\
\text { erita/umum/reaksi-cepat- } \\
\text { polisi-di-pekanbaru- } \\
\text { berhasil-gagalkan-aksi-2- } \\
\text { pelaku-teror-bom.html } \\
\text { di akses pada } \\
\text { November 2016 }\end{array}$ \\
\hline
\end{tabular}




\begin{tabular}{|c|c|c|}
\hline 6. & $\begin{array}{l}\text { Sejumlah pejabat dan politikus di Riau tengah } \\
\text { dihantui teror bom molotov. Dalam dua hari di } \\
\text { Kota Pekanbaru, dua teror terjadi dan menyasar } \\
\text { rumah Wakil Bupati Bengkalis Muhammad serta } \\
\text { Ketua NasDem Riau Iskandar Husein } 21 \text { Oktober } \\
2016 \text {. }\end{array}$ & $\begin{array}{l}\text { http://riaupos.co/34598- } \\
\text { berita-lima-mantan-napi- } \\
\text { teroris-bom-balijw- } \\
\text { marriot-berada-di- } \\
\text { riau.html\#.WBgIqoMrLIU } \\
\text { di akses pada } 20 \\
\text { November 2016 }\end{array}$ \\
\hline
\end{tabular}

\section{Sumber: Data Modifikasi Penulis 2016}

Dari beberapa kasus diatas di lingkungan masyarakat, adanya menunjukan bahwa Provinsi Riau pikiran negatif terhadap masyarakat berkemungkinan menjadi tempat pendatang baru dan adanya rasa takut beroperasinya jaringan teroris. Polda untuk mengunjungi daerah di isukan Riau harus mewaspadai ini karena teroris merupakan salah satu kejahatan yang luar biasa bagi negara kita ini. Terlebih lagi Provinsi Riau sebagian besar wilayahnya merupakan daerah perkebunan berpotensi sebagai sarang terorisme.

Adanya tindakan teroris tersebut berdampak dalam sistem sosial budaya Indonesia, dampak tersebut dapat memberikan sebuah pandangan bahwasannya aksi terorisme tersebut mendapatkan pengertian bahwasanya teror tersebut telah menciptakan adanya disintegrasi nilai sosial terhadap nilai pancasila.

Dengan adanya terorisme yang berkembang pada saat ini, tentu berdampak diberbagai bidang, baik itu dibidang sosial, ekonomi, dan politik. Dampak sosial seperti, terjadi kekacauan terdaptnya teroris. Dampak ekonomi seperti kurangnya minat infestor untuk memanamkan saham ke negara yang di isukan adanya teroris, kurangnya minat turis untuk datang ke negara tersebut, dan terjadinya inflansi ekonomi di sebabkan turunnya harga saham yang melonjak tinggi. Sementara dalam bidang politik seperti terjadinya ketegangan politik bilateral atau multilateral di sebabkan ada keterkaitan warga negara lain dan terbaginya fokus pemerintahan sehingga menimbulkan isu pengalihan permasalahan yang terjadi di dalam internal pemerintahan. Melihat luasnya dampak yang mungkin ditimbulkan oleh aksi teroris, maka perlu dilakukan upaya pencegahan, dan salah satunya ujung tombaknya adalah Direskrimsus Polda Riau. Berdasarkan latar belakang diatas, penulis tertarik 
untuk melakukan penelitian dengan judul “Upaya Pencegahan Terorisme (Studi Kasus Ditreskrimum Polda Riau)".

\section{Konsep Teror, Teroris, Terorisme}

Menurut kamus besar bahasa Indonesia Teror merupakan perbuatan sewenang-wenang, kejam, kengerian untuk menciptakan ketakutan, kengerian, kekejaman oleh seseorang maupun golongan. Teroris merupakan orang yang melakukan tindakan kekerasan untuk menciptakan ketakutan demi tujuan tertentu. Sementara Terorisme merupakan tindakan kekerasan untuk menciptakan ketakutan demi tujuan politik, agama , dan ideologi. Bukan berarti jika kita menakut-nakuti seseorang tanpa tujuan tersebut kita bisa dikatakan sebagai teroris.

Disebut 'teror-isme’ karena dipandang sebagai suatu yang digandrungi (menjadi suatu paham atau isme) dengan menggunakan terror sebagai serana pemaksa kehendak dalam peyelesaian suatu permasalahan. Demi tujuan pemahamam yang lebih khusus sehingga dilakukanlah sebuah tindakan teror, agar paham atau isme yang mereka sampaikan bisa di dengar (Mubarak, 2012:241).
Terorisme mengandung arti kata “menakut-nakuti” kata tersebut berasal dari bahasa latin "terere" yang berarti membuat gemetar atau menimbulkan kengerian. Istilah terror (terror) atau ketakutan (the fear) tersebut digunankan Pemerintahan negara Perancis dalam kaitannya dengan perlawanan terhadap perlawanan revolusioner (Thontowi, $2013: 6)$.

Namun, istilah "terorisme" sendiri pada 1970-an dikenakan pada beragam fenomena, dari bom yang meletus di tempat-tempat publik sampai dengan kemiskinan dan kelaparan. Beberapa pemerintahan bahkan menstigma musuh-musuhnya sebagai teroris dan aksi-aksi mereka disebut terorisme. Karena itu istilah ini juga rentan dipolitisasi. (Maulani et al, 2002:6)

Menurut Konvensi PBB tahun 1939, terorisme adalah segala bentuk tindak kejahatan yang ditujukan langsung kepada negara dengan maksud menciptakan bentuk teror terhadap orang-orang tertentu atau kelompok orang atau masyarakat luas.

Menurut Ensiklopedia Indonesia tahun 2000, terorisme adalah kekerasan atau ancaman kekerasan yang diperhitungkan sedemikian rupa untuk 
menciptakan suasana ketakutan dan bahaya dengan maksud menarik perhatian nasional atau internasional terhadap suatu aksi maupun tuntutan.

Terorisme secara kasar merupakan istilah yang digunakan untuk penggunaan kekerasan terhadap warga sipil untuk tujuan politik, dalam skala lebih kecil dari pada perang. Menurut wikipedia Terorisme adalah seranganserangan terkoordinasi yang bertujuan membangkitkan perasaan teror terhadap sekelompok masyarakat. Berbeda dengan perang, aksi terorisme tidak tunduk pada tata cara peperangan seperti waktu pelaksanaan yang selalu tiba-tiba dan target korban jiwa yang acak serta seringkali merupakan warga sipil.

Menurut ketentuan hukum Indonesia, aksi terorisme dikenal dengan istilah Tindak Pidana Terorisme. Indonesia memasukkan terorisme sebagai tindak pidana, sehingga cara penanggulangannya pun menggunakan hukum pidana sebagaimana tertuang dalam peraturan pemerintah pengganti Undang-Undang (PERPU) Republik Indonesia Nomor 1 tahun 2002 yang kemudian diperkuat menjadi UndangUndang (UU) Nomor 15 tahun 15 tahun 2003. Judul Perpu atau Undang-Undang tersebut adalah Pemberantasan Tindak Pidana Terorisme.

Pasal 1 ayat 1 Perpu No. 1 Tahun 2002 menyatakan bahwa tindak pidana terorisme adalah segala perbuatan yang memenuhi unsur pidana sesuai dengan ketentuan Perpu. Perbuatan tersebut termasuk yang sudah dilakukan ataupun yang akan dilakukan. Dua hal ini tercantum dalam pasal 6 dan pasal 7 (Perpu, 2002). Terkait dengan unsurunsur tindak pidana terorisme, ada perbedaan antara pasal 6 dan 7. Adapun Pasal 6 menyatakan sebagai berikut :

Pelaku tindak pidana terorisme adalah setiap orang yang dengan sengaja menggunakan kekerasan atau ancaman kekerasan yang menimbulkan suasana teror atau rasa takut terhadap orang secara meluas, atau menimbulkan korban yang bersifat massal, dengan cara merampas kemerdekaan atau hilangnya nyawa dan harta benda orang lain. mengakibatkan kerusakan atau kehancuran terhadap objek-objek vital yang strategis, atau lingkungan hidup, atau fasilitas publik, atau fasilitas internasional.

Dari pasal 6 di atas, dapat disarikan bahwa suatu aksi atau tindakan dapat digolongkan sebagai tindak pidana 
terorisme bila mengandung unsur berikut:

a. Dilakukan dengan sengaja

b. Menggunakan kekerasan atau ancaman kekerasan

c. Menimbulkan suasana teror atau rasa takut secara luas

d. Menimbulkan korban massal, baik dengan cara merampas kemerdekaan atau dengan menghilangkan nyawa atau harta benda orang lain

e. Mengakibatkan kerusakan pada objek-objek vital

Sementara pasal 7 menyebutkan:

Setiap orang yang dengan sengaja menggunakan kekerasan atau tindakan ancaman kekerasan yang dimaksudkan untuk menimbulkan suasana teror atau rasa takut terhadap orang secara luas atau mengakibatkan kerusakan atau kehancuran terhadap objek-objek vital yang strategis, atau lingkungan hidup, atau fasilitas publik, atau fasilitas internasional dipidana dengan pidana penjara paling lama seumur hidup.

Pasal 7 di atas menyebutkan bajwa suatu aksi atau tindakan dpaat digolongkan sebagai tindak pidana terorisme bila mengandung unsur-unsur sebagai berikut : a. Dilakukan dengan sengaja

b. Menggunakan kekerasan atau ancaman kekerasan

c. Dimaksudkan untuk menimbulkan korban massal

d. Mengakibatkan kerusakan atau kehancuran terhadap objek-objek vital yang strategis, atau lingkungan hidup, atau fasilitas publik, atau fasilitas internasional.

\section{a. Ciri-ciri Terorisme}

Menurut beberapa literatur dan referensi dapat disimpulkan bahwa ciriciri terorisme adalah :

1. Organisasi yang baik, berdisiplin tinggi \& militant (Thontowi. 2013:82)

2. Mempunyai tujuan politik, ideologi tetapi melakukan kejahatan kriminal untuk mencapai tujuan(Mustofa, 2012:67).

3. Tidak mengindahkan normanorma universal yang berlaku, seperti agama, hukum dan HAM(Thontowi, 2013:84).

4. Memilih sasaran yang menimbulkan efek psikologis yang tinggi untuk menimbulkan rasa takut dan mendapatkan 
publikasi yang luas(Reich, 2006:56).

5. Menggunakan cara-cara antara lain seperti : pengeboman, penculikan, penyanderaan, pembajakan dan sebagainya yang dapat menarik perhatian massa atau publik(Mubarak, 2012:243).

Berdasarkan motivasi dapat dibedakan dalam empat kategori. Kategori pertama, berkaitan dengan ideologi dan keyakinan, yakni kelompok teroris yang dimotivasi oleh ajaran agama biasanya dididik dalam lembagalembaga pendidikan keagamaan dalam waktu yang lama dan dipersiapkan untuk aktifitas terorisme.

Kategori kedua, kelompok yang tereksploitasi. Kelompok inilah yang mendominasi aksi-aksi terorisme di Indonesia. Walaupun pelaku mendapatkan indoktrinasi dan sekaligus proyeknya dari anggota dalam jaringan teroris di Indonesia, tetapi sebagian besar tidak mengenal dengan baik orang telah mencuci otaknya "brainwashing”, mereka yang dapat dieksploitasi menjadi suicide bombers (pelaku bom bunuh diri) adalah yang memiliki perasaan bersalah atau merasa hidupnya tak bermakna.
Sebagian besar dari mereka berasal dari segmen pemuda yang bermasalah secara psikologis dan sosial, serta bukan berasal dari kelompok religius.

Ciri-cirinya pun berbeda dengan kategori pertama. Mereka tidak direkrut di mesjid tetapi di jalan. Tentu mengeksploitasi segmen masyarakat seperti ini sangat mudah dan inilah yang menjadi fenomena terorisme di Indonesia.

Kategori ketiga, dimotivasi oleh balas dendam atas kekerasan oleh rezim Orde Baru terhadap anggota keluarga mereka, kelompok ini dapat berasal dari keluarga Darul Islam (DI). Hanya saja untuk saat ini tentu sangat susah mendapatkan keluarga DI yang masih mengalami trauma kekerasan yang diterima oleh keluarga mereka.

Sedangkan kategori keempat adalah kelompok separatis yang berkembang di Indonesia. Pada kenyataannya, kelompok itu telah melakukan transformasi kepada gerakan politik dan berdamai dengan pemerintah Indonesia.

\section{b. Bentuk-bentuk Teror.}

Berdasarkan cara-cara yang digunakan, teror dapat dibedakan :

1) Teror Fisik yaitu teror untuk menimbulkan ketakutan, 
kegelisahan memalui sasaran fisik jasmani dalam bentuk pembunuhan, penganiayaan, pemerkosaan, penyanderaan penyiksaan dan sebagainya, sehingga nyata-nyata dapat dilihat secara fisik akibat tindakan teror.

2) Teror Mental, yaitu teror dengan menggunakan segala macam cara yang bisa menimbulkan ketakutan dan kegelisahan tanpa harus menyakiti jasmani korban (psikologi korban sebagai sasaran) yang pada tingkat tertentu dapat menimbulkan tekanan batin yang luar biasa akibatnya bisa gila, bunuh diri, putus asa dan sebagainya.

Berdasarkan skala sasaran, teror dapat dibedakan :

1) Teror Nasional, yaitu teror yang ditujukan kepada pihak-pihak yang ada pada suatu wilayah dan kekuasaan negara tertentu, yang dapat berupa : pemberontakan bersenjata, pengacauan stabilitas nasional, dan gangguan keamanan nasional.

2) Teror Internasional yaitu tindakan teror yang diktujukan kepada bangsa atau negara lain diluar kawasan negara yang didiami oleh teroris, dengan bentuk :

a) Dari Pihak yang kuat kepada pihak yang lemah. Dalam bentuk penjajahan, intervensi, agresi dan perang terbuka.

b) Dari Pihak yang Lemah kepada Pihak yang kuat. Dalam bentuk pembajakan, gangguan keamanan internasional, sabotase, tindakan nekat dan berani mati, pasukan bunuh diri, dan sebagainya.

\section{c. Requitmen Kelompok Teroris}

Konsep pencucian otak merupakan terminologi yang sangat umum. Dari perspektif komunikasi, pelaku kejahatan ini mendekati calon korban dengan proses persuasi. Proses yang secara sadar bertujuan untuk mempengaruhi orang berperilaku sesuatu.

Pencucian otak sangat bisa berhasil dengan proses persuasi yang sangat profesional. Bisa dengan teknik lowball atau juga sugesti. Teknik lowball, biasanya diawali dengan sebuah permintaan halus. Permintaan ringan 
yang disodorkan berlangsung terus menerus. Misalnya, seseorang meminta pertolongan secara materil.

Kejahatan dengan teknik lowball ini dilakukan dengan jangka waktu lama dan dilakukan secara berulang-ulang pada korban yang sama. Semakin lama, si pelaku semakin memberikan permintaan yang semakin berat. Teknik pencucian otak ini dilancarkan kepada calon korban secara sadar. Sedangkan, teknik sugesti digunakan si pelaku dengan menyerang alam tak sadar calon korban. Biasanya masyarakat lebih akrab dengan teknik gendam. Calon korban diserang dalam posisi tenang yakni pada saat istirahat atau tahap gelombang otak mengarah tenang (Wibowo,2012:202).

Modus yang digunakan para “pencuci otak" untuk melaksanakan tujuannya adalah mencari dana dengan doktrin jihad. Pertama, pelaku akan mengajak si korban untuk hijrah, lalu berjihad, dan terakhir memintanya berinfaq.

Pendekatan yang dilakukan para pelaku juga tergolong singkat. Sejak pertama kali mengenal korban hingga melakukan eksekusi, mereka butuh waktu dua minggu.

Tidak hanya itu, sasaran korban pun beragam. Tidak ada golongan khusus, atau jenis kelamin tertentu, yang jelas Mardigu meminta semua pihak waspada jika ada orang-orang asing yang mengajak kenalan dengan cara yang sangat intens.

\section{d. Tujuan Teroris}

Menurut Milla (2010) teroris memiliki dua tujuan, yaitu:

a. Tujuan Jangka Pendek, meliputi :

1. Memperoleh pengakuan dari masyarakat lokal, nasional, regional maupun dunia internasional atas perjuangannya.

2. Memicu reaksi pemerintah, over reaksi dan tindakan represif yang dapat mengakibatkan keresahan di masyarakat.

3. Mengganggu, melemahkan dan mempermalukan pemerintah, militer atau aparat keamanan lainnya.

4. Menunjukkan ketidak mampuan pemerintah dalam melindungi dan mengamankan rakyatnya.

5. Memperoleh uang atau perlengkapan.

6. Mengganggu dan menghancurkan sarana 
komunikasi, $\quad$ informasi maupun transportasi.

7. Mencegah atau menghambat keputusan dari badan eksekutif atau legislatif.

8. Menimbulkan mogok kerja.

9. Mencegah mengalirnya investasi dari pihak asing atau program bantuan dari luar negeri.

10. Mempengaruhi jalannya pemilihan umum.

11. Membebaskan tawanan yang menjadi kelompok mereka.

12. Membalas dendam.

b. Tujuan Jangka Panjang, meliputi :

1. Menimbulkan perubahan dramatis dalam pemerintahan, seperti revolusi, perang saudara atau perang antar negara.

2. Mengganti ideologi suatu negara dengan ideologi kelompoknya.

3. Menciptakan kondisi yang menguntungkan bagi pihak teroris selama perang gerilya.

4. Mempengaruhi kebijakan pembuat keputusan baik dalam lingkup lokal, nasional, regional atau internasional.

5. Memperoleh pengakuan politis sebagai badan hukum untuk mewakili suatu suku bangsa atau kelompok nasional.

\section{e. Perkembangan Terorisme}

Pada awal Abad 20an, ideologi yang berdasarkan Nasionalisme dan revolusi adalah merupakan suatu kekuatan yang paling utama yang terus di kembangkan menghadapi terorisme. Bila Perjanjian Versailles menggambar kembali peta Eropa setelah Perang Dunia I oleh kehancuran kekaisaran AustroHungarian yang mengakibatkan terciptanya negara-negara baru, ini diakui sebagai prinsip penentuan nasib sendiri untuk negara dan kelompok etnis. Hal ini mendorong etnis minority dan penduduk asli tidak menerima pengakuan untuk mengkampanyekan kemerdekaan atau otonomi. Namun, dalam banyak kasus, penentuan nasib sendiri adalah terbatas pada negaranegara Eropa dan kelompok etnik di Eropa sementara yang lain tidak boleh, terutama penguasa kekuasaan Eropa, telah menciptakan kepahitan dan periode konflik jangka panjang di daerah-daerah jajahan atau koloninya. (Thontowi; 2013: 33).

Secara khusus, Negara-Negara Arab merasa bahwa mereka telah di khianati. Mereka percaya akan kemerdekaan, mereka sangat kecewa, 
pertama ketika Perancis dan Inggris diberi kewenangan atas tanah mereka, dan kemudian ketika Inggris mengijinkan imigrasi Zionist masuk ke wilayah Palestina sesuai dengan isi Deklarasi Balfour.

Sejak akhir Perang Dunia II, terorisme telah mempercepat perkembangannya menjadi komponen utama dalam konflik kontemporer. Terutama di gunakan segera setelah perang sebagai unsur utama antipenjajahan dan perannya semakin meluas. Dalam Pelayanan di berbagai aspirasi dan ideologi, terkadang terorisme digantikan dengan bentuk konflik lain. Hal ini menjadi senjata jarak jauh yang mampu mencapai efek global lebih kurang seperti roket jarak jauh. Ia juga telah dibuktikan dapat menjadi alat signifikan dari diplomasi internasional dan terbukti beberapa negara cenderung untuk menggunakannya (Chomsky,1991:46).

Nampaknya hasil yang cepat dan goncangan yang besar dari terorisme telah menjadi pertimbangan sebagai jalan singkat menuju kemenangan. Kelompok Revolusioner yang tidak rela untuk memberikan waktu dan sumber daya dalam mengatur kegiatan politik akan bergantung pada "propaganda dari aksi yang dibuat" untuk menggerakkan aksi massa yang besar. Hal ini menunjukkan bahwa kelompok pergerakan kecil dapat menumbangkan setiap pemerintah melalui penggunaan terror hal ini dipercayai oleh oleh kaum revolusioner.

Saat ini, motif terorisme lebih sering dikaitkan dengan dimensi moral yang luas seperti nilai, ideologi, agama, ketidakadilan tatanan dan struktur sosial maupun konstelasi dunia. Namun tidak dipungkiri, bahwa sekarang ini, Islam diidentikan sedemikian rupa sebagai agama yang mengusung terorisme. Perkembangan Islam, baik secara institusi dan ataupun individualnya, telah mengkhawatirkan dunia internasional sedemikian rupa tanpa alasan yang jelas sama sekali.

Stigma Islam yang melahirkan kekerasan terus dimunculkan setiap hari di berbagai belahan dunia. Hingga umat pun perlahan-lahan mulai percaya bahwa Islam mengusung kekerasan seperti itu, padahal tak sedikitpun agama ini menganjurkan kekerasan. Dalam berperang, Islam telah mengajarkan syarat dan ketentuan seperti tidak sembarangan, tidak boleh membunuh non-kombatan, tidak boleh merusak 
pepohonan, tidak boleh berlebihan, dan sebagainya.

Terorisme gaya baru mengandung beberapa karakteristik:

1. Ada maksimalisasi korban secara sangat mengerikan.

2. Keinginan untuk mendapatkan liputan di media massa secara internasional secepat mungkin.

3. Tidak pernah ada yang membuat klaim terhadap Terorisme yang sudah dilakukan.

4. Serangan Terorisme itu tidak pernah bisa diduga karena sasarannya sama dengan luasnya seluruh permukaan bumi.

\section{f. Perkembangan Terorisme di Indonesia}

Terorisme sebuah fenomena yang mengganggu. Aksi terorisme seringkali melibatkan beberapa negara. Sponsor internasional yang sesungguhnya adalah negara besar. Harus dipahami bahwa terorisme sekarang telah mendunia dan tidak memandang garis perbatasan internasional.

Resolusi Dewan Keamanan PBB Nomor 1373 yang menetapkan Al Qaeda pimpinan Osama bin Laden berada dibalik tragedi 11 September 2001 dan dinyatakan sebagai Terorisme yang harus diberantas oleh dunia telah menimbulkan berbagai reaksi dikalangan masyarakat internasional diantaranya muncul tanggapan yang menyatakan bahwa justru Amerika Serikat lah yang mensponsori aksi teror di dunia dengan membentuk konspirasi global yang didukung sekutunya dengan tujuan menghancurkan Islam di Indonesia tanggapan tersebut santer ketika munculnya pernyataan PM Senior Singapura Lee Kuan Yeuw bahwa Indonesia "Sarang Teroris" yang serta merta seluruh masyarakat Indonesia menolak pernyataan tersebut dengan membakar gambar/patung PM Singapura (Wibowo; 2012:75) .

Walaupun Polri berhasil menangkap para pelaku serta mengungkap jaringan Terorisme yang berada dibalik peristiwa tersebut, namun hal ini sangat berdampak pada semua aspek kehidupan bermasyarakat dan bernegara. Atas hasil pengungkapan kasus peledakan bom Bali reaksi masyarakat yang semula cenderung apriori terhadap bom Bali, seolah-olah semua ini adalah hasil rekayasa internasional bersama pemerintah, kini telah bergeser dan mampu melihat fakta secara objektif melalui proses penanganan dan pengungkapan berbagai macam serta 
semua jaringan dan para pelaku serta taktik yang sering dilakukan oleh para teroris adalah (Agus, 2014: 17-28) :

1) Bom, taktik yang sering digunakan adalah pengeboman. Dalam dekade terakhir ini sering terjadi aksi teror yang dilaksanakan dengan menggunakan bom, baik di Indonesia maupun di luar negeri, dan hal ini kedepan masih mungkin terjadi.

2) Pembajakan, pembajakan sangat populer dilancarkan oleh kelompok teroris. Pembajakan terhadap pesawat terbang komersial pernah terjadi di beberapa negara, termasuk terhadap pesawat Garuda Indonesia di Don Muang Bangkok pada tahun 1981. Tidak menutup kemungkinan pembajakan pesawat terbang komersial masih akaan terjadi saat ini dan massa yang akan datang, baik di Indonesia maupun di luar negeri.

3) Pembunuhan, adalah bentuk aksi teroris yang tertua dan masih digunakan hingga saat in. Sasaran dari pembunuhan ini seringkali telah diramalkan, teroris akan mengklaim bertanggungjawab atas pembunuhan yang dilaksanakan. Sasaran dari pembunuhan ini biasanya adalah pejabat pemerintah, penguasa, politisi dan aparat keamanan. Dalam sepuluh tahun terakhir tercatat 246 kasus pembunuhan oleh teroris seluruh dunia.

4) Penculikan, tidak semua penghadangan ditujukan untuk membunuh. Dalam kasus kelompok gerilya Abu Sayaf di Filipina, penghadangan lebih ditujukan untuk menculik personel, seperti yang dilakukan oleh kelompok GAM terhadap kameraman RCTI Ersa Siregar dan Fery Santoro di Aceh. Penculikan biasanya akan diikuti dengan tuntutan imbalan berupa uang atau tuntutan politik lainnya.

5) Penyanderaan, perbedaan antara penculikan dan penyanderaan dalam dunia terorisme sangat tipis. Kedua bentuk operasi ini seringkali meimiliki pengegertian yang sama. Penculik biasanya meennan korbannya di tempat 
tersembunyi dan tuntutannya adalah berupa materi dan uang, sedangkan penyanderaan biasanya menahan sandera di tempat umum ataupun di dalam hutan seperti yang dilakukan oleh kelompok Kelly Kwalik di Papua yang menyandera tim peneliti Lorenz pada tahun 1996. Tuntutan penyannderaan lebih dari sekedar materi. Biasanya tuntutan politik lebih sering dilemparkan pada kasus penyanderaan ini.

\section{Peran Kepolisian Dalam Pencegahan}

\section{Teroris}

Secara umum, pencegahan kejahatan diaplikasikan pada berbagai upaya yang ditujukan untuk mengontrol prilaku kriminal. Setiap upaya pencegahan kejahatan ditujukan sebagai tindakan-tindakan yang dilakukan sebelum kejahatan itu terjadi, yaitu dengan mempersempit peluang terjadinya kejahatan. Termasuk juga kejahatan terorisme, setidaknya kepolisian harus lebih memfokuskan diri kepada pencegahan dibandingkan penindakan (Dermawan,2013: 14).

Fakta bahwa rasio polisi dan penduduk di Indonesia sangat tidak rasional. Tepatnya, 1:1.000. Satu polisi untuk 1.000 orang penduduk. Padahal, menurut Perserikatan Bangsa-Bangsa (PBB), rasio idealnya adalah 1:350. Dengan jumlah yang minimal tersebut maka pelayanan dan perlindungan kepada penduduk memang lalu tidak bisa maksimal. Namun sudah menjadi tugas dan kewajiban polisi untuk bekerja secara optimum dalam menjaga keamanan dan ketertiban.

Kegiatan pencegahan anti teror ditujukan untuk mengurangi kemungkinan terjadinya aksi teror. Kegiatan ini meliputi teknik pencegahan. Pencegahan kejahatan sebagai suatu upaya yang memerlukan tindakan apapun yang dirancang untuk mengurangi tingkat sebenarnya dari kejahatan dan/atau hal-hal yang dapat dianggap sebagai kejahatan. Kejahatan murni yang ditujukan untuk memperkuat target serta prosedur untuk mendeteksi aksi teror yang terencana. Perencanaan dan latihan adalah unsur penting dalam program penanggulangan teror. Kegiatan preventif meliputi perencanaan, tindakan pencegahan, persiapan dan latihan sebelum insiden terjadi. Selama tahap ini pertimbangan diberikan kepada penelitian, pengumpulan informasi dan intelijen, tindakan pencegahan, 
perencanaan yang mendalam serta latihan yang intensif. Pengalaman membuktikan bahwa pencegahan adalah cara terbaik untuk melawan terorisme Intelijen.

Pengumpulan keterangan atau intelijen mengenai teroris adalah hal terpenting dalam memerangi teroris. Siapa teroris, kapan, dimana dan bagaimana ia akan melancarkan aksinya adalah pertanyaan yang harus terjawab dalam pengumpulan intelijen ini. Informasi yang dikumpulkan meliputi bidang sosial, ekonomi dan politik dari suatu daerah.

\section{Teori}

Pencegahan kejahatan harus menyerang kedua tingkat kejahatan dan viktimisasi, baik yang sebenarnya maupun perasaan ketakutan. Kejadiankejadian teror yang selama ini terjadi di Indonesia merupakan sinyal bahwa Indonesia merupakan salah satu target operasi organisasi terorisme baik internasional maupun domestik. Bagi Indonesia pencegahan dan pemberantasan terorisme memerlukan kecermatan pengamatan atas kultur, kondisi masyarakat, dan stabilitas politik pemerintahan.
Menurut Darmawan(2013) dalam bukunya Strategi Kepolisian dalam Pencegahan Kejahatan, upaya-upaya yang dilakukan oleh Kepolisian di Implementasikan melalui upaya:

1. Upaya Preventif

Mengingat keterbatasan dan upaya penal maka perlu adanya penanggulangan kejahatan yang tidak hanya bersifat penal, akan tetapi juga dapat menggunkan sarana-sarana atau kebijakan yang sifatnya non penal. Upaya non penal merupakan suatu pencegahan kejahatan, dimana dilakukan sebelum kejahatan itu terjadi, sehingga upaya ini lebih dikenal dengan upaya yang sifat nya preventif atau pencegahan. Ini seharusnya harus lebih diutamakan dari upaya yang sifatnya represif.

Demikian pula WA. Bonger mengatakan dilihat dari efisiensi dan efektifitas upaya pencegahan lebih baik dari pada upaya yang bersifat represif. Dalam dunia kedokteran kriminal telah di sepakati suatu pemikiran bahwa mencegah kejahatan lebih baik dari pada mencoba mendidik penjahat menjadi baik kembali, lebih disini juga berarti lebih mudah, lebih murah dan lebih mencapai tujuannya. 
Langkah preventif yang di ambil

oleh kepolisian dalam rangka pencegahan terhadap tindakan pidana terorisme yaitu :

a. Peningkatan pengamanan dan pengawasan terhadap senjata api.

b. Peningkatan pengamanan terhadap sistem transportasi.

c. Peningkatan pengamanan terhadap sarana publik.

d. Peningkatan pengamanan terhadap sistem komunikasi.

e. Peningkatan pengamanan terhadap fasilitas diplomatik dan kepentingan asing.

f. Peningkatan kesiagaan menghadapi serangan teroris.

g. Peningkatan pengamanan terhadap fasilitas internasional.

h. Pengawasan terhadap bahan peledak dan bahan-bahan kimia yang dapat dirakit menjadi bom.

2. Upaya Preemtif

Kebijakan yang melihat akar masalah utama penyebab terjadinya kejahatan melalui pendekatan sosial, pendekatan situasional dan pendekatan kemasyarakatan untuk menghilangkan unsur Potensi Gangguan (Faktor Korelatif Kriminogen).

Upaya preemtif dapat dilakukan melalui cara-cara sebagai berikut : a) Pencerahan ajaran agama untuk mengeliminir ekstrimisme dan radikalisasi pemahaman ajaran agama oleh kelompokkelompok fundamentalis garis keras.

b) Penyelesaian kebijakan politik dan pemerintahan :

- Merespon tuntutan politik teroris dengan kebijakan politik

- Pelibatan kelompok-kelompok radikal yang potensial yang mengarah kepada tindakan teror dalam penyelesaian konflik secara damai.

- Penawaran konsesi politik bagi kelompok-kelompok yang bergerak dibawah tanah menjadi gerakan formal secara konstitusional.

c) Pelibatan partai politik dan organisasi kemasyarakatan.

d) Penetapan secara tegas organisasi teroris dan organisasi terkait sebagai organisasi terlarang dan membubarkannya.

e) Pemberlakukan hukuman mati terhadap pelaku terorisme di Indonesia.

3. Upaya Represif

Upaya penanggulangan kejahatan pada hakekatnya merupakan suatu usaha 
untuk pengamanan masyarakat (sosial defence) agar masyarakat dapat terhindar dari kejahatan atau setidak-tidaknya mengendalikan kejahatan yang terjadi agar berada dalam batas-batas toleramsi masyarakat. Langkah represif yang dilakukan oleh Kepolisian dalam upaya pencegahan terhadap terorisme adalah sebagai berikut :

a. Pembentukan badan penanggulangan tindak pidana terorism, serta pembentukan satuan khusus sebagai langkah pemberantasan terorisme.

b. Penyerbuan terhadap tempat persembunyian pelaku terorisme.

c. Penjatuhan sanksi pidana yang tegas terhadap pelaku terorisme yang telah terbukti bersalah berdasarkan bukti-bukti yang ada.

\section{Kesimpulan}

Berdasarkan hasil penelitian diatas, dapat disimpulkan bahwa Ditreskrimum Polda Riau telah melakukan berbagai macam upaya dalam mencegah terorisme tidak terjadi di Provinsi Riau ini. Upaya tersebut berupa, upaya preventif atau pencegahan seperti razia rutin didaerah-daerah perbatasan, upaya preemtif atau penyuluhan seperti himbauan-himbauan melalui baliho, dan represif atau penangkapan. Dalam melakukan pencegahan tersebut Ditreskrimum Polda Riau juga mendapati kendala seperti kurangnya kepedulian masyarakat terhadap masyarakat lainnya, kurang efektifnya kinerja RT/RW setempat dalam mengawasi warganya serta daerah-daerah yang menjadi sasaran teroris merupakan daerah yang sulit diakses.

\section{Saran}

a. Kepada pihak Kepolisian harus meningkatkan kesadaran masyarakat mengenai bahaya teroris,serta lebih meningkatkan pemantauannya terhadap para pelaku terorisme maupun mantan pelaku terorisme guna memutus mata rantai terorisme tersebut.

a. Kepada masyarakat dari pihak pemerintahan lebih peka terhadap masyarakat, dan adil kepada setiap lapisan masyarakat agar tidak tercipta jaringan-jaringan teroris lainnya. Dari kebanyak teroris tercipta karena tidak mendapatkan keadilan dari negara dan merasa tidak dipedulikan.

b. Masyarakat khususnya masyarakat Riau harus lebih sadar lagi 
mengenai bahaya terorisme serta lebih berpartisipasi untuk memberikan informasi kepada pihak Kepolisian jika ada warga-warga yang mencurigakan. Dari pihak Kepolisian sangat membutuhkan bantuan dari masyarakat karena informasi-informasi tersebut akan mempermudah pihak Kepolisian dalam mencegah kejahatan yang ada khususnya kejahatan terorisme.

\section{Daftar Pustaka}

Agus, 2014, Darurat Terorisme, Daulat Press, Jakarta.

Chomsky, Noam, 1991, International Terrorism in the Real World, Mizan Anggota IKAPI, Bandung.

Derwmawan, Muhammad Kemal, 2013, Memahami Strategi Pencegahan Kejahatan, Departemen Kriminologi Fisip UI, Jakarta.

Fachmi, 2011, Kepastian Hukum Mengenai Putusan Batal Demi Hukum Dalam Sistem Peradilan Pidana Indonesia, PT Ghalia Indonesia Publishing, Bogor.

Hagan, E. Frank, 2013, Pengantar Kriminologi Teori, Metode, dan Perilaku Kriminal Ed7. Jakarta: PT. Fajar Interpratama Mandiri.

Kadartama, A, 2007,Membangun Kultur Kepolisian, PT. Forum Media Utama, Jakarta.

Maulani, et al, 2005, Bagaimana Mengatasi Terosisme, Zikrul, Jakarta.
Milla, Mirra Noor, 2010, Mengapa Memilih Jalan Teror: Analisis Psikologis Pelaku Teror, Gajah Mada University Press, Yogyakarta.

Mustofa, Muhammad, 2005, Metode Penelitian Kriminologi, UI Perss, Jakarta.

Nitibaskara, Ronny Rahman, 2009, Perangkap Penyimpangan dan Kejahatan,

Yayasan Pengembangan Kajian Ilmu Kepolisian, Jakarta.

Sohaludin, 2008, Kitap Undang-undang Hukum Pidana, Transmedia Pustaka, Jakarta.

Santoso, Boedi, 1998, Seminar Nasional Polisi dan Masyarakat Dalam Era Reformasi, Fakultas Hukum , Fakultas Ilmu Sosial dan Politik, Universitas Indonesia , Jakarta.

Santoso, Topo, 2000, Polisi dan Jaksa: Keterpaduan Atau Pergaulan?, Pusat Studi Peradilan Pidana Indonesia, Depok.

Reich, Walter, 2009, Origins Terorism: Tinjauan Psikologi, PT. Grafindo Persada, Jakarta.

Thontowi, Jawahir, 2013, Terorisme Negara: Kerjasama Konspiratif Menjinakan Yogyakarta.

Islam Fundamentalis, UII Press,

Anwar, Yesmil \& Adang, 2009, Sistem Peradilan (Konsep Komponen \& Pelaksanaan Dalam Penegakan Hukum di Indonesia), Widya Padjadjaran, Malang.Wibowo, Ari, 2012, Hukum Pidana Terorisme, Graha Ilmu, Yogyakarta. 
Jurnal :

Mustafa Imam,2012, TERORISME: ANTARA AKSI DAN REAKSI (Gerakan Islam

Radikal Sebagai Respon Terhadap Imperialisme Modern), RELIGIA Vol. 15 No. 1, http://grahailmu.co.id/previewpdf /978-979-756-870-2-883.pdf, 22 Desember 2016.

Mubarak Zulfi, 2012, Fenomena Terorisme di Indonesia: Kajian Aspek Teologi,

Ideologi dan Gerakan, Jurnal Studi Masyarakat Islam Volume 15 ,

http://ejournal.umm.ac.id/index.p hp/salam/article/view/1633, 22 Desember 2016.

\section{Undang-undang :}

Pasal 1 ayat 1 Perpu No. 1 Tahun 2002

Pasal 6 Perpu Tahun 2002.

Undang-Undang Nomor 15 Tahun 2003 Tentang Tindak Pidana Terorisme.

Seminar :

Meliala, Adrianus, Seminar Kriminologi: Teorisme Dalam Perspektif Kriminologi, diprsentasikan pada 27

Desember 2016, Pekanbaru.

\section{Internet :}

http://webcache.googleusercontent.com/ search?q=cache:http://news.liputan6.co m/read/26440/kasus-bom-natal-dipekanbaru-mulai-terkuak (diakses 20 November 2016).

http://daerah.sindonews.com/read/77419 1/24/densus-88-tangkap-dua-teroris-diriau-1377157180 (diakses 20 November 2016).

http://www.beritasatu.com/nasional/133 418-agus-sunyoto-napi-teroris-tanjunggusta-dibekuk-di-riau.html (diakses 20 November 2016).

http://www.riaupos.co/96023-beritawarga-pekanbaru-terduga-terorispernah-tersandung-kasusnarkoba.html\#ixzz4NaEnQk77(diakses 20 November 2016)

https://www.goriau.com/berita/umum/re aksi-cepat-polisi-di-pekanbaru-berhasilgagalkan-aksi-2-pelaku-teror-bom.html (diakses 20 November 2016).

http://riaupos.co/34598-berita-limamantan-napi-teroris-bom-balijw-marriotberada-di-riau.html\#.WBgIqoMrLIU (diakses 20 November 2016).

http://id.wikipedia.org/wiki/Definisi_ter orisme (diakses 22 November 2016) 